\title{
Analysis of the Competitiveness of Xiamen Port and Kaohsiung Port
}

\author{
X.Q. Guo \\ Navigation College, Jimei University, Xiamen, Fujian, China
}

J.S. Huang

Navigation College, Jimei University, Xiamen, Fujian, China

\begin{abstract}
In order to achieve economies of scale in port production about Xiamen and Kaohsiung Harbors, enhance the overall competitiveness of the Strait of East and West Coast ports and promote regional economic development in the Taiwan Strait under the context of cross-strait direct flights. This paper analyzes the competitiveness of Xiamen and Kaohsiung Harbors by the method of principal component, and then propose cooperative strategies: improve the level of port infrastructure, build modern container transport system, build exchange and cooperation between Xiamen port and Kaohsiung port, enhance the economical competitiveness of the port city, establish electronic platform together.
\end{abstract}

KEYWORD: Xiamen Port; Kaohsiung Port; Principal Component Analysis; strategies

\section{INTRODUCTION}

It has formed the container Trunk ports of Kaohsiung and Xiamen across the Strait. Xiamen port is 165 sea miles away from Kaohsiung port. With the rapid development of mainland china economy, the container throughput of Xiamen Port increases year by year. Now, the container throughput of Xiamen Port ranks 17th position worldwide. However, the container throughput of Kaohsiung Port is hovering in the quasi-million TEU in recent years, and it falls outside the top ten from the third largest container port around the world gradually. The gap between Xiamen port and Kaohsiung port is narrowing $(\mathrm{Gao}, 2012)$.In order to achieve economies of scale in port production about Xiamen and Kaohsiung Harbors, enhance the overall competitiveness of the Strait of East and West Coast ports and promote regional economic development in the Taiwan Strait under the context of cross-strait direct flights, Xiamen port and Kaohsiung port should be cooperation instead of competition. In view of this, the paper uses the method of principal component analysis to analysis the competitiveness of Xiamen and Kaohsiung Harbors, and then propose cooperation strategies.

\section{RESEARCH METHODS AND ESTABLISHING OF EVALUATION}

Principal component analysis is a multivariate statistical analysis method which elect fewer number of important variables from multiple variables by linear transformation (Liu, 2010).

The mathematical model of Principal component analysis is:

$$
\begin{aligned}
& F_{1}=a_{11} Z X_{1}+a_{21} Z X_{2}+\cdots \cdots+a_{p 1} Z X_{p} \\
& F_{2}=a_{12} Z_{1}+a_{22} Z X_{2} \cdots \cdots+a_{p 2} Z X_{p} \\
& \cdots \cdots \\
& F_{p}=a_{1 m} Z X_{1}+a_{2 m} Z X_{2}+\cdots \cdots+a_{p m} Z X_{p}
\end{aligned}
$$

$a_{1 i}, a_{2 i}, \ldots \ldots, a_{p i}(i=1, \ldots \ldots, m)$ are eigenvectors which are corresponded to eigenvalues of the $X$ 's covariance matrix, $Z_{1}, Z_{1}, \ldots \ldots, Z_{\mathrm{p}}$ are the variables of the original value standardized.

\subsection{Objects of this study}

Objects of this study are Xiamen Port and Kaohsiung Port. Select the ports which have a strong container port competitiveness and development potential in China as comparison objects. The ports are Shanghai port, Ningbo-Zhoushan Port,

Foundation item: Soft Science Fund Project of Fujian (2013R0077), The Key Project of Fujian about Association for Science and Technology Think Tank (2014011)

Author brief introduction: Guo Xiaoqing (1989-), Female, Master Degree Candidate, Engaged in the Research of Transportation Planning and Mangement, E-mail: 872781849@qq.com, Tel:15859234673.

Corresponding author: HuangJianshe (1958-), Male, Professor, Master Tutor, Mainly Engaged in the Research of International Shipping Technology and Shipping Management, E-mail:hh109@126.com 
Lianyungang port, Shenzhen port, Guangzhou port, Zhanjiang Port and Fuzhou port.

Based on principles of systematic, comparability, objectivity and operability $(\mathrm{Li}, 2010)$. the paper establishs evaluation index system as following:

$\mathrm{X} 1$ :Channel depth X2:The number of port berths $\mathrm{X} 3$ : the number of 10 thousand-ton above berth
X4:Port city GDP X5:Container Throughput X6:Cargo Throughput X7: The growth rate of port city GDP X8:Average annual growth rate of container throughput $\mathrm{X} 9$ :Average annual growth rate of Cargo Throughput

Table 1 Details of original data

\begin{tabular}{|c|r|r|r|r|r|r|r|r|r|}
\hline & X1 & X2 & X3 & X4 & X5 & X6 & X7 & X8 & X9 \\
\hline Xiamen Port & 16 & 145 & 64 & 3018 & 801 & 19100 & 9.5 & 10.22 & 14.71 \\
\hline Fuzhou Port & 17 & 178 & 47 & 4700 & 198 & 12800 & 11.5 & 12.78 & 10.45 \\
\hline Kaohsiung Port & 16 & 190 & 80 & 3688 & 994 & 11503 & 0.4 & 0.75 & -4.56 \\
\hline Shanghai Port & 10 & 1183 & 243 & 20602 & 3362 & 73559 & 7.7 & 4.12 & 5.96 \\
\hline Ningbo-Zhoushan Port & 18 & 601 & 137 & 8060 & 1735 & 74401 & 9.2 & 9.58 & 8.75 \\
\hline Lianyun Port & 14 & 55 & 50 & 1785 & 549 & 20200 & 11.8 & 13.21 & 14.98 \\
\hline Guangzhou Port & 17 & 845 & 68 & 15420 & 1531 & 45100 & 11.6 & 6.96 & 5.64 \\
\hline Shenzhen Port & 10 & 160 & 69 & 14500 & 2328 & 22800 & 10.5 & 2.4 & 4.69 \\
\hline Zhanjiang Port & 15 & 125 & 34 & 2630 & 45.2 & 18500 & 14.35 & 9 & 10 \\
\hline
\end{tabular}

\subsection{The calculation results by principal component analysis}

First, there are some differences in aspects of magnitudes and dimensions that the paper should normalize the raw data by SPSS15.0 statistical analysis.

Second, to extract the main factor by principal component analysis. Main factor extraction principle is that the main components corresponding eigenvalues must be greater than the previous principal components 1. Shown in Table 2, this paper $\mathrm{m}=3$, that is extracted three main ingredients. Calculated that the correlation coefficient matrix eigenvalues, variance contribution rate and cumulative contribution rate, the first three factors cumulative contribution rate of $91.150 \%$, to meet the cumulative contribution rate over $85 \%$.

Table 2 Details of Total Variance Explained

\begin{tabular}{|c|c|c|c|c|c|c|}
\hline \multirow[b]{2}{*}{ Component } & \multicolumn{3}{|c|}{ Initial Eigenvalues } & \multicolumn{3}{|c|}{ Extraction Sums of Squared Loadings } \\
\hline & Total & $\%$ of Variance & Cumulative \% & Total & $\%$ of Variance & Cumulative $\%$ \\
\hline 1 & 4.923 & 54.697 & 54.697 & 4.923 & 54.697 & 54.697 \\
\hline 2 & 2.157 & 23.962 & 78.659 & 2.157 & 23.962 & 78.659 \\
\hline 3 & 1.124 & 12. 491 & 91.15 & 1.124 & 12. 491 & 91.15 \\
\hline 4 & 0.499 & 5.548 & 96.698 & & & \\
\hline 5 & 0.137 & 1.523 & 98.221 & & & \\
\hline 6 & 0.104 & 1.157 & 99.379 & & & \\
\hline 7 & 0.042 & 0.465 & 99.843 & & & \\
\hline 8 & 0.014 & 0.157 & 100 & & & \\
\hline 9 & $6.26 \mathrm{E}-17$ & $6.95 \mathrm{E}-16$ & 100 & & & \\
\hline
\end{tabular}

Third, The table 3 shows the indicators which is the number in the port berths, the number of berths, port city GDP, container throughput and cargo throughput have higher load in the first principal component, so that the first principal component can reflect the main information of these indicators, namely the external conditions, infrastructure and management ability. The second principal component can reflect the future development potential of ports. And the third principal component can reflect the port of natural conditions.

Table 3 Details of component Matrix ${ }^{2}$

\begin{tabular}{|c|c|c|c|}
\hline & \multicolumn{3}{|c|}{ Component } \\
\hline & 1 & 2 & 3 \\
\hline $\mathrm{X1}$ & -0.533 & a. 009 & 0.809 \\
\hline $\mathrm{x} 2$ & o. 845 & o. 356 & o. 284 \\
\hline $\mathrm{x} 3$ & o. 887 & o. 222 & o. 164 \\
\hline $\mathrm{x} 4$ & o. 895 & a. 209 & -0.19 \\
\hline xs & ‥ 96 & a. 102 & -0.153 \\
\hline $\mathrm{xe}$ & o. 745 & o. 51 & ‥ 354 \\
\hline XT & -0.393 & o. 757 & -0.354 \\
\hline $\mathrm{x} s$ & -0.671 & 0. 682 & D. 172 \\
\hline $\mathrm{xg}$ & -0.507 & 0. 793 & -0.15 \\
\hline
\end{tabular}

The last, by SPSS15.0 software using the regression method to calculate the coefficient of factor score function, get the following factor score function:

$$
\begin{aligned}
& F_{1}=-0.240 Z X_{1}+0.381 Z X_{2}+0.400 Z X_{3}+0.403 Z X_{4} \\
& -0.433 Z X_{5}+0.336 Z_{6}-0.177 Z X_{7} \\
& -0.302 Z_{8}-0.229 Z X_{9} \\
& \mathrm{~F}_{2}=0.006 Z \mathrm{X}_{1}+0.242 \mathrm{ZX} \mathrm{X}_{2}+0.151 \mathrm{ZX} \mathrm{X}_{3}+0.142 \mathrm{ZX} \\
& +0.069 \mathrm{ZX}_{5}+0.347 \mathrm{ZX}_{6}+0.515 \mathrm{ZX}_{7} \\
& +0.464 Z \mathrm{X}_{8}+0.540 \mathrm{ZX} \\
& \mathrm{F}_{3}=0.763 Z \mathrm{X}_{1}+0.268 Z \mathrm{X}_{2}+0.155 Z \mathrm{ZX}_{3}-0.179 \mathrm{ZX} 4 \\
& -0.144 Z X_{5}+0.334 Z X_{6}-0.334 Z X_{7} \\
& +0.162 \mathrm{ZX}_{8}-0.141 \mathrm{ZX} \mathrm{X}_{9}
\end{aligned}
$$

Principal component comprehensive calculation model is as follows:

$$
W F_{i}=\lambda_{i} / \sum_{i=1}^{m} \lambda_{i}
$$


Principal component comprehensive score computation formula is as follows:

$$
\mathrm{F}=\mathrm{WF}_{1} \times \mathrm{F}_{1}+\mathrm{WF}_{2} \times \mathrm{F}_{2}+\mathrm{WF}_{3} \times \mathrm{F}_{3}
$$

Calculated ports competitiveness comprehensive evaluation scores by SPSS15.0 software as shown in table 4.

Table 4 Details of scores and ranking

\begin{tabular}{|c|c|c|c|c|c|c|c|c|}
\hline & F1 & Rank & F2 & Rank & F3 & Rank & F & Rank \\
\hline Xiamen Port & -0.721 & 6 & 0.2323 & 6 & 0.04844 & 5 & -0.365 & 5 \\
\hline Fuzhou Port & -0.939 & 8 & 0.2554 & 5 & 0.2558 & 4 & -0.461 & 7 \\
\hline Kaohsiung Port & 0.1584 & 5 & -2.455 & 9 & 0.80907 & 2 & -0.44 & 6 \\
\hline Shanghai Port & 2.0768 & 1 & 0.6751 & 2 & -0.2995 & 6 & 1.3825 & 1 \\
\hline Ningbo-Zhoushan Port & 0.3694 & 4 & 0.7311 & 1 & 1.5771 & 1 & 0.6299 & 2 \\
\hline Lianyun Port & -0.94 & 9 & 0.5866 & 3 & -0.5386 & 8 & -0.484 & 8 \\
\hline Guangzhou Port & 0.3874 & 3 & 0.3761 & 4 & 0.59836 & 3 & 0.4133 & 3 \\
\hline Shenzhen Port & 0.5159 & 2 & -0.586 & 8 & -1.95 & 9 & -0.112 & 4 \\
\hline Zhanjiang Port & -0.907 & 7 & 0.1845 & 7 & -0.501 & 7 & -0.564 & 9 \\
\hline
\end{tabular}

\subsection{The analysis results}

Shown in table 4, Shanghai port ahead of the other ports. And Ningbo - Zhoushan port and Guangzhou port belong to the second group. Shenzhen, Xiamen, Kaohsiung ports belong to the third group,. Fuzhou port, Lianyungang port, Zhanjiang harbour belong to the fourth group. In recent years, with the high-speed development of the mainland, the competitiveness of xiamen rapid ascension to the fifth. But because of the shortage of supply of goods, the backward management level, the competitiveness of the xiamen still lags behind of several ports which is relatively developed in the pearl river delta and Yangtze river delta. And kaohsiung port caused by a lack of their own conditions, less supply of goods, weak economic situation factors, leading to the port comprehensive competitiveness level dropped to sixth place.

From the port of natural conditions, score of kaohsiung port is 0.80907, ranked second; Xiamen is 0.04844, ranked fifth. Thus, kaohsiung port condition is superior.

From factors of the external conditions, infrastructure and management ability, xiamen is 0.72144 , kaohsiung port is 0.15841 . While kaohsiung harbor ranked fifth and lags behind several other developed ports, its score well ahead of xiamen port. And This shows that kaohsiung harbor as a port of the tradition world's top ten, due to various reasons dropped out of the top ten, but its internal and external conditions and operation ability in the harbour is still remarkable. In the ranking, xiamen port is ahead of zhanjiang harbour, fuzhou port, lianyungang port, but the leading advantage is not obvious.

From the future development potential of the port, xiamen scored 0.2323 , ranked sixth, and kaohsiung port is -2.4552 , ranked the last. Xiamen score was obviously higher than that of kaohsiung port, along with the continuous development of xiamen, then the port "Matthew effect" is highlighted, so the future development potential of Xiamen port is tremendous (Zhang, 2005).And kaohsiung harbor score is in the negative, it reflects the weakness of
Taiwan's economy in recent years has a big negative impact on the development potential of Taiwan port. And Kaohsiung harbor water condition is superior, but shoreline resources are limited, domain is narrow, and Lack of economic hinterland, so its potential development lags behind. Overall, xiamen port also relatively backward in the ranking. This suggests that xiamen port development level has risen steadily in recent years, but due to economic hinterland is narrow and supply of goods is lack, so the development dynamics is insufficient.

Based on the above analysis, this paper puts forward to the Collaborative development strategies between Xiamen port and Kaohsiung harbor.

\section{THE COOPERATIVE STRATEGIES BETWEEN XIAMEN PORT AND KAOHSIUNG HARBOR}

Firstly, promote the port infrastructure construction and expand the service function together. To speed up infrastructure construction of ports, port service functions and business scope of business, it should be based on the factors such as the coastline, wharf depth conditions, the rear land resources situation and the existing wharf infrastructure situation. And then unified layout planning and construction projects, so that Xiamen port and Kaohsiung port can get sustainable development. Plan the construction of the container ports together, Focus on container logistics business. Cooperation between the two port should focus on the internal management, port terminal operation efficiency, service level of ports, and the expand of value-added services.

Secondly, Build a modern container transport system and expand transportation business together. Establish a modern container transport system which regards Xiamen port and Kaohsiung port as pivotal ports, Fuzhou port, quanzhou port, keelung harbor, taichung port as the main feeder ports, other ports for feeding ports (Chu, 2014). Xiamen and Kaohsiung ports should cooperate by means of 
shipping companies and port construction, operation mode terminals, to integrate resources, construction, operation and management about container terminals together. And the two ports should work together to guide shipping company to formulate reasonable port project in route configuration, so that achieve the purpose of collaboration.

Thirdly, establish communication port cooperation mechanism, and integrate resources of Xiamen and Kaohsiung ports. The two ports should work together to establish a communication port cooperation mechanism and plan how to cooperate. Formed alliance which is Kaohsiung-centered, and then build an international shipping center in Taiwan Strait (Huang, 2012). Make high efficiency of kaohsiung port combined with Hinterland advantage of xiamen port to form a complementary advantages, so that improve the port service ability and radiation ability of xiamen port rapidly, at the same time expand hinterland of kaohsiung port and improve the market competitiveness of kaohsiung harbor.

Fourthly, encourage mutual investment and improve the economic competitiveness of the port cities. Xiamen and kaohsiung port shipping industry should speed up to build the long-term mechanism which is conducive to deepening port shipping industries cooperation, that improve the investment environment together. Port enterprises can explore each other holdings, joint ventures. Looking for specific projects in ports, bonded warehousing, shipping and logistics and other aspects to invest cooperation. Develop island together.

Fifthly, build a public information service platform and optimize the port environment. Fujian E-port should dock to Taiwan GATT network, to achieve the integration of customs, ports and trade. And they should form a highly informationization, highly intelligent and highly networked integrated logistics information system which is based on the future development of the ports.

\section{CONCLUSION}

There is not only competition between xiamen portsand kaohsiung port, but also the favorable conditions of cooperation between them. In the ECFA era, the two sides have extensive cooperation foundation, so they should make full use of their own advantages and seize the port development opportunity as to promote the cooperation of both sides. In order to realize the ports cooperation and promote the competitiveness of the ports, Xiamen port and kaohsiung port can take the measures such as improve port infrastructure construction, build modern container transport system, establish communication port cooperation mechanism, encourage mutual investment, build the public information service platform and so on.

\section{REFERENCES}

[1] Gao Ling. Empirical Analysis of Container Port in Fujian and Taiwan Cooperative Development under ECFA. Beijing University of Chemical Technology, 2012(3):49-53

[2] Liu Dahai. SPSS15.0 Statistical Analysis-from Entry to Master. Tsinghua University Press, 2010.

[3] Li Zhao. Competition and Cooperation between Xiamen Port and Kaohsiung Port. China Port, 2010.2:16-18.

[4] Huang Jianshe. Analysis and Research of Xiamen Port Development, China Maritime, 2012(1):9-13

[5] Chu Liangyong. Strategies to expand economic hinterland of Xiamen, Journal of Dalian Maritime University, 2014(2):21-23

[6] Zhang Chuanguo, A Quantitative Comparative Study of Comprehensive Competitiveness between Xiamen Port and Kaohsiung Port, Taiwan Research, 2005(2):25-29. 